\begin{tabular}{ccc}
\hline International Journal of Current Research in \\
Biosciences and Plant Biology \\
\hline EXCELLENT \\
PUBLISHERS
\end{tabular}

Original Research Article

doi: https://doi.org/10.20546/ijcrbp.2018.501.006

\title{
Anatomical Studies on Association of Endophytic Fungi in Ormocarpum cochinchinense and Enicostema axillare
}

\author{
D. Nagarajan ${ }^{1 *}$ and R. Pandian ${ }^{2}$ \\ 1Department of Plant Biology and Plant Biotechnology, Presidency College, Chennai-600005, \\ Tamil Nadu, India \\ 2Department of Higher Education, Govt. of Tamil Nadu, India \\ *Corresponding author.
}

\begin{tabular}{|c|c|}
\hline Article Info & ABSTRACT \\
\hline $\begin{array}{l}\text { Date of Acceptance: } \\
27 \text { December } 2017\end{array}$ & \multirow{4}{*}{$\begin{array}{l}\text { The present investigation has been carried out to determine the anatomical features of } \\
\text { Leaf, Stem, and Root of two medicinal plants belonging to different families, namely } \\
\text { Ormocarpum cochinchinense (Lour.) Merr. belonging to Papilionaceae (Fabaceae) and } \\
\text { Enicostema axillare (Lam.) Rayanal, belonging to Gentianaceae. Ormocarpum cochinchinense } \\
\text { a shrub which is extremely efficacious in mending bone fracture as per the folklores } \\
\text { claims in the villages of Tamil Nadu, India and Enicostema axillare (Lam.) Rayanal,is a } \\
\text { perennial herb called as chotachirayita in Hindi, vallari, vellaruku in Malayalam, } \\
\text { vellarugu in Tamil. The leaves of Enicostema axillare are fed to cattle to increase appetite. } \\
\text { The whole plant of Indian Whitehead treat diabetes mellitus, rheumatism, abdominal } \\
\text { ulcers, hernia, swelling, itching, malaria and insect poisoning. Apart from this it is used } \\
\text { as stomachic and laxative, and blood purifier in dropsy. It is proposed that the properties } \\
\text { of medicinal plants are either inherited from endophytic fungi or endophytic fungi are } \\
\text { inheriting the properties of native plant. Thus, establishing the plant - microbe } \\
\text { interaction is of importance. Considering the medicinal importance of these plants, which } \\
\text { are used in the treatment of different disease, they are taken for the study to evaluate the } \\
\text { presence of endophytic fungi in different parts of the plants (leaf, stem, and roots). The } \\
\text { attempt was made to identify the presence of hyphae of endophytic fungi through } \\
\text { anatomical studies. The study established the presence of fungal mycelium in Leaf, Stem } \\
\text { and Root in Enicostema axillare and Leaf and Root in Ormocarpum cochinchinense. This } \\
\text { study is the first report in establishing the presence of endophytic fungi in internal tissues } \\
\text { of medicinal plants through anatomical studies. }\end{array}$} \\
\hline $\begin{array}{l}\text { Date of Publication: } \\
\text { 06 January } 2018\end{array}$ & \\
\hline Keywords & \\
\hline $\begin{array}{l}\text { Anatomy } \\
\text { Endophytic fungi } \\
\text { Enicostema axillare } \\
\text { Ormocarpum cochinchinense } \\
\text { Plant microbe interaction }\end{array}$ & \\
\hline
\end{tabular}

\section{Introduction}

The genus Ormocarpum cochinchinense (Lour.) Merr. belonging to Papilionaceae (Fabaceae) is a shrub distributed in dry evergreen to dry deciduous forests, moist deciduous and semi - evergreen forests. Global distribution to south and south East Asia. In India distribution occurs in the 
Kasarangode, Idukki, Kannur, Thrissur and Palakkad districts of Kerala, Coimbatore, Kancheepuram, Pudukkottai, Selam, Thiruvallur, Thiruvannamalai, Thiruchirappalli, Tirunelveli, Virudhunagar, Vellore and Vilupuram districts in the state of Tamil Nadu. The plant is extremely efficacious in mending bone fracture hence its local name is "Elumbotti" (Samy et al., 2008). It is erect subshrub, leaves pinnately $10-13$ foliate, leaflets, alternate, $2-3 \times 1.2 \mathrm{~cm}$. obovate - oblong, obtuse; petiole slender; stipule ovate. Flowers in slender axillary, 6- $10 \mathrm{~cm}$ long, racemes, bract ovate; calyx $6 \mathrm{~mm}$ long, lobes ovate, acute, hairy corolla $8 \mathrm{~mm}$, long, pink; standard clawed, wing, 5 x $4 \mathrm{~mm}$, orbicular, auricled; stamens monadelphous, spitting later; ovary linear, many - 0vuled, hispid. Pods 2- 3 cm long, 1- 4 jointed; joints oblong with soft echinate process. Flowering and fruiting; August November.

The medicinal plants are the richest bio - resources in drugs of traditional medicinal systems, modern medicines, nutraceuticals, food supplements, folk medicines, pharmaceuticals intermediate chemical entitled for synthetic drugs. The roots of the plant Ormocarpum cochinchinense are considered to be tonic and stimulant which is used in the treatment of lumbago and paralysis, mending bone fractures but at present its use is known only to handful of villagers in the tropical dry evergreen forest areas of Tamil Nadu for healing fractures (Maria John et al., 2011).

Enicostema axillare (Lam.) Raynal. Is a herb, growing in sandy localities and marshy places. Eastern and southern Africa, Eritrea to Southern Africa, Namibia, Angola and also India, Sri Lanka, and Indonesia. The plant is sometimes gathered from the wild for local medicinal use, and is occasionally cultivated for this purpose, Enicostema axillare grows up to $20 \mathrm{~mm}$ height; stem 3 - ribbed, terete, glabrous, leaves opposite, oblong lanceolate, $1-8-3 \times 06-1 \mathrm{~cm}$, cuneate at base entire at margin, acute, recurred at apex, glabrous; 3 - nerved at base; petiole sessile, flowers $7 \mathrm{~mm}$ across, white, axillary, cluster, sessile. Calyx campanulate, 5 lobed lobe oblonceolate, $3.5 \mathrm{~mm}$ long, hyaline at margin, corolla tubular tube cylindrical, $04 \mathrm{~mm}$ long, greenish at middle, lobe 5; filament small, $0.5 \mathrm{~mm}$ long; anther 3, angled $1.3 \mathrm{~mm}$ long, acute at apex. Ovary ellipsoid $2.7 \mathrm{~mm}$ long; 1 occulted; ovules many; style slender, $1 \mathrm{~mm}$ long; stigma capitates, $0.3 \mathrm{~mm}$ long capsules ellipsoid, 04 x $2.5 \mathrm{~mm}$ long 2- valved; seeds many rounded - subglobose, $0.3 \mathrm{~mm}$ long, reticulate brown. Flowering June - January, and fruiting time throughout year.

It is found almost throughout 66 India up to an altitude of about 450m, from Punjab and the Gang tic plains southwards, most commonly in coastal areas. The whole plant of Indian Whitehead treat diabetes mellitus, rheumatism, abdominal ulcers, hernia, swelling, itching, malaria and insect poisoning (Vishwakarma et al., 2010).

It is proposed that the properties of medicinal plants are either inherited from endophytic fungi or endophytic fungi are inheriting the properties of native plant. Thus, establishing the plant - microbe interaction is of importance. Considering the medicinal importance of these plants, which are used in the treatment of different disease, they are taken for the study to evaluate the presence of endophytic fungi in different parts of the plants (leaf, stem, and roots). The attempt was made to identify the presence of hyphae of endophytic fungi through anatomical studies.

\section{Materials and Methods}

\section{Collection of specimens}

The plant specimens for the study were collected from Magamai Thirumani Village belonging to the District of Thiruvannamalai, Tamil Nadu State in India (Fig. 1). The plants, Ormocarpum cochinchinense (Fig. 2a) and Enicostema axillare (Fig. 2b), were identified (Gamble, 1935; Hennry et al., 1987) and deposited in the herbaria of Madras Presidency College Chennai, and Prof. P. Jayaraman, Ph.D. Plant Anatomy Research Centre (PARC) West Tambaram, Chennai. The healthy tissues showing no external symptoms were taken for the study. 


\section{Tiruvannamalai District}
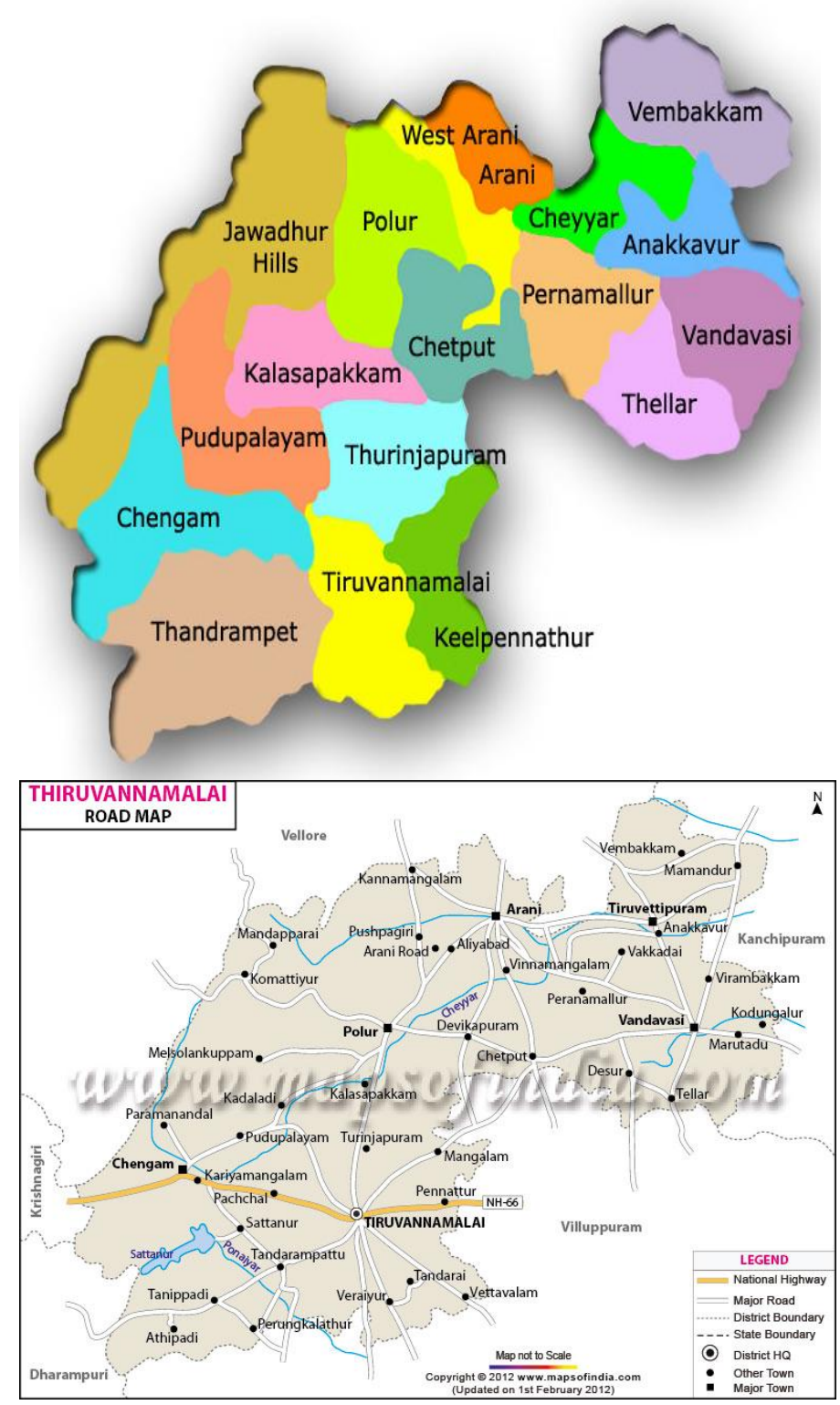

Fig. 1: Maps showing the area of plant collection.

\section{Impregnation}

The required samples of different organs were cut and removed from the plant and fixed in FAA (Formalin-5ml+ Acetic acid-5ml $+70 \%$ Ethyl alcohol-90ml). After $24 \mathrm{hrs}$ of fixing, the specimens were dehydrated with graded series of tertiary -Butyl alcohol as per the schedule given by Sass (1940). Infiltration of the specimens was carried by gradual addition of paraffin wax (melting point $58-60^{\circ} \mathrm{C}$ ) until TBA solution attained super saturation. The specimens were cast into paraffin blocks.

\section{Sectioning}

The paraffin embedded specimens were sectioned with the help of Rotary Microtome. The thickness of the sections was 10-12 $\mu \mathrm{m}$. Dewaxing of the sections was by customary procedure (Johansen, 1940). The sections were stained with Toluidine blue as per the method published by O'Brien et al. (1964).

Since Toluidine blue is a polychromatic stain. The staining results were remarkably good; and some cytochemical reactions were also obtained. The dye rendered pink colour to the cellulose walls, blue to the lignified cells, dark green to suberin, violet to the mucilage, blue to the protein bodies etc. wherever necessary, sections were also stained with safranin and Fast-green and Potassium Iodide (for Starch)

For studying the stomatal morphology, venation pattern and trichome distribution, paradermal sections (sections taken parallel to the surface of leaf) as well as clearing of leaf with $5 \%$ sodium hydroxide or epidermal peeling by partial maceration employing Jeffrey's maceration fluid (Sass, 1940) were prepared. Glycerine mounted temporary preparations were made for macerated/cleared materials. Powdered materials of different parts were cleared with $\mathrm{NaOH}$ and mounted in glycerine medium after staining. Different cell component were studied and measured.

\section{Photomicrographs}

Microscopic descriptions of tissues are supplemented with micrographs wherever necessary. Photographs of different magnifications were taken with Nikon labphoto 2 microscopic Unit. For normal observations bright field was used. For the study of crystals, starch grains and lignified cells, polarized light was employed. Since 
these structures have birefringent property, under polarized light they appear bright against dark background. Magnifications of the figures are indicated by the scale-bars. Descriptive terms of the anatomical features are as given in the standard Anatomy books (Esau, 1964).
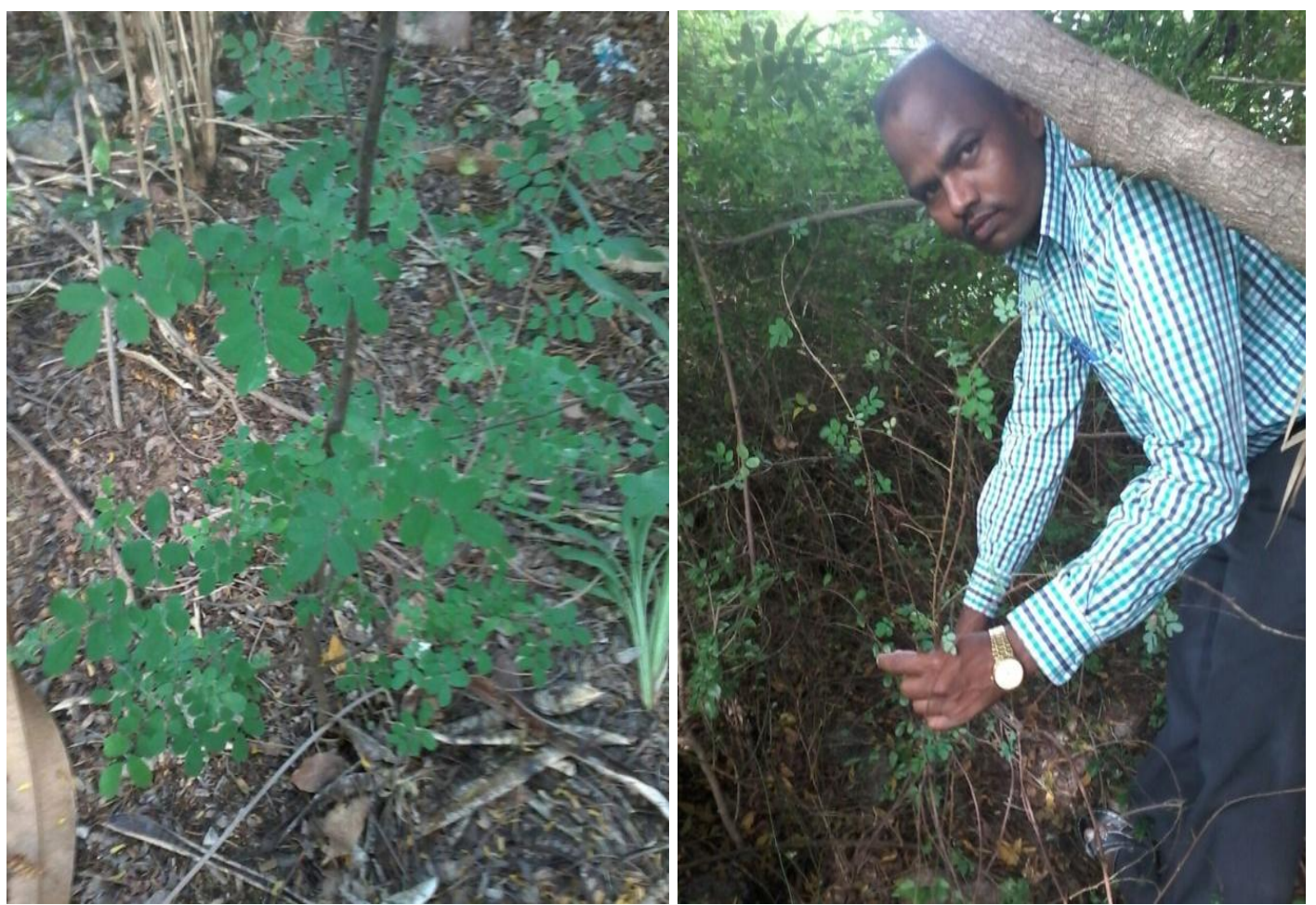

Fig. 2a: The habit of Ormocarpum cochinchinense.
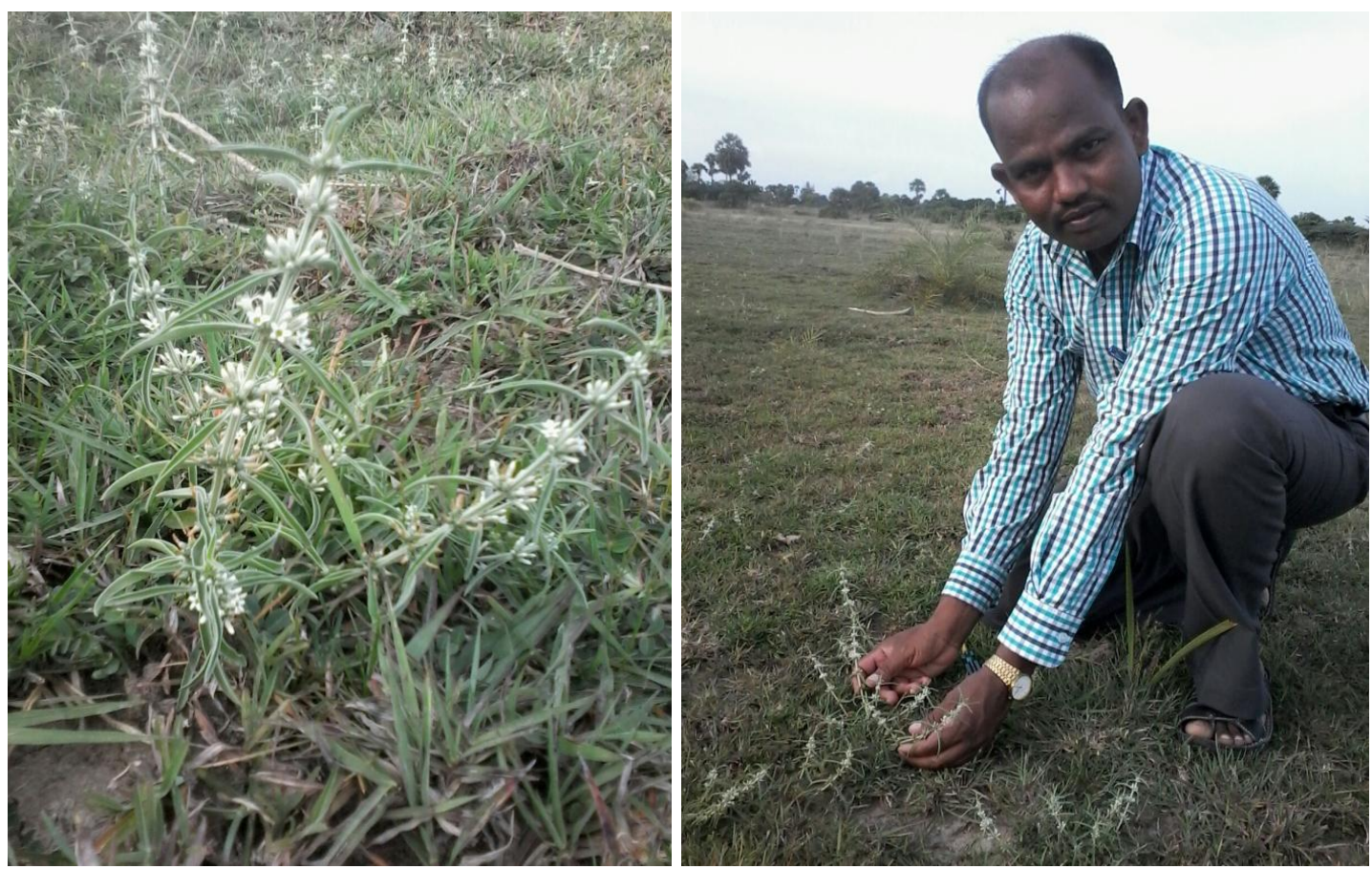

Fig. 2b: The habit of Enicostema axillare.

D. Nagarajan and R. Pandian (2018) / Anatomical Studies on Association of Endophytic Fungi in Ormocarpum cochinchinense 


\section{Results and Discussion}

\section{Ormocarpum cochinchinense fungal association}

\section{Leaf}

Fungal association is recorded both in the leaf and roots. Fungus is seen less in the tissues of the leaf than in the root.
In the leaf fungal mycelium is seen in the mesophyll tissue, near the vascular bundle of the midrib. In the intercellular spaces of the xylem elements in the form of class region (Fig. 3). Fungal mycelium also is located in between the lower epidermal cells and sub epidermal cells of the midrib. In the lamina, the fungus mycelium is seen ramifying in the middle space between abaxial and adaxial epidermal layers.
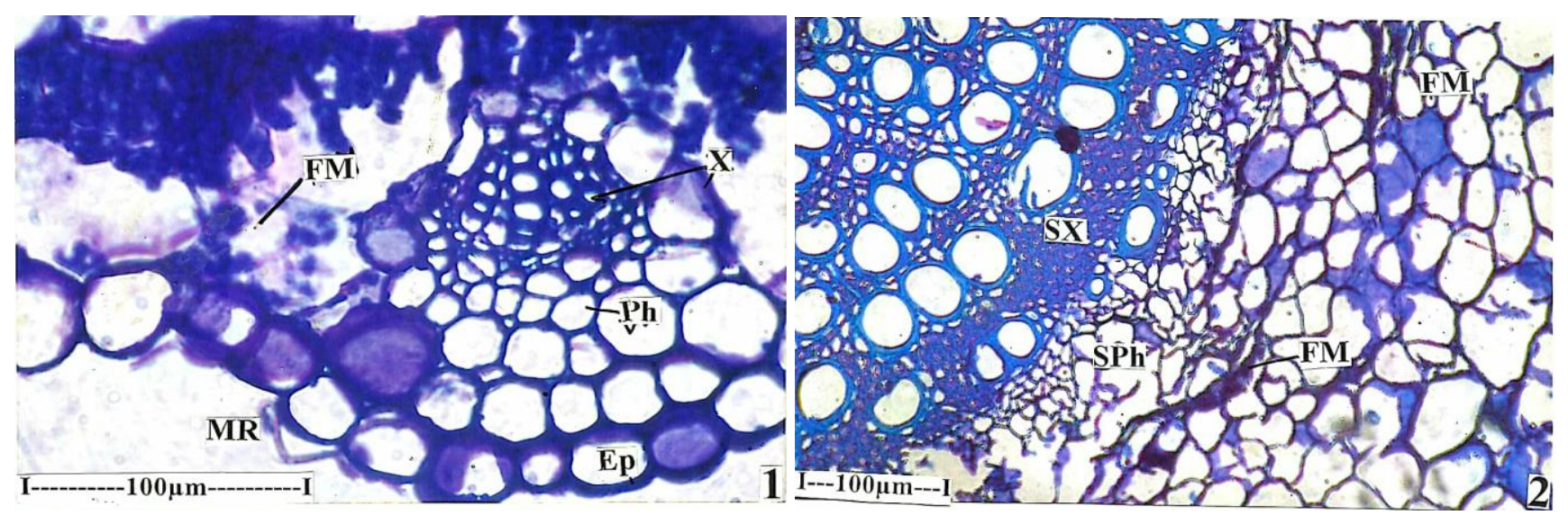

Fig. 3: Ormocarpum cochinchinense. (1) T.S. of leaf showing fungal mycelium near the vascular bundle. (2) T.S. of vascular cylinder with fungus spreading near with secondary phloem (FM - Fungal Mycelium; X - Xylem; Ph - Phloem; MR - Midrib; Ep - Epidermis; SX- Secondary xylem; SPh- Secondary Phloem; SE- Secondary xylem).

\section{Root}

In the root, fungus is abundant, in the intercellular spaces of the cortex as well in the phloem zone (Fig. 4). The fungus does not seem to penetrate the xylem elements. The fungus is restricted only along the outer border of the phloem. The fungus appears thick and dark and it gradually becomes thin when it penetrates its neighbouring ground parenchyma cells. The cortical cells and phloem elements do not get crushed due to the invasion of the fungal mycelium.

\section{Enicostema axillare fungal association}

\section{Leaf}

In the leaf, fungus is found diffusely distributed in the mesophyll tissue. Since the epidermis is thickly cuticularized, the fungus seems to enter in to mesophyll through the stomatal pores (Fig. 5). The fungal mycelium has spread in the intercellular spaces of the mesophyll tissues. It is dense in the region around the vascular strands.

\section{Stem}

The fungus occurs mostly in cortical tissues (Fig. 6). The epidermal cells have thick cell cuticle which may not allow the penetration of the fungus and so the fungus seems to have entered through the stomata located on the epidermis. After reaching the cortical cells, the fungus spreads freely in the intercellular spaces of the cells as well as it intrudes into the cell lumen.

In the cell lumen, the fungus forms thick, brushshaped clusters or repeatedly branched cluster. Due to the presence of a continuous cylinder of cortical fibres', the fungus is not able to enter the vascular bundles or the pith. 


\section{Root}

In the root, the fungal mycelium occurs mostly with cortical parenchyma (Fig. 7). The mycelium is intercellular in position. In some of the sections the fungus protrudes into the cell lumen where it form repeatedly branched cluster. Dense mass of spherical spores are often seen in the lumen of the cortical cells.
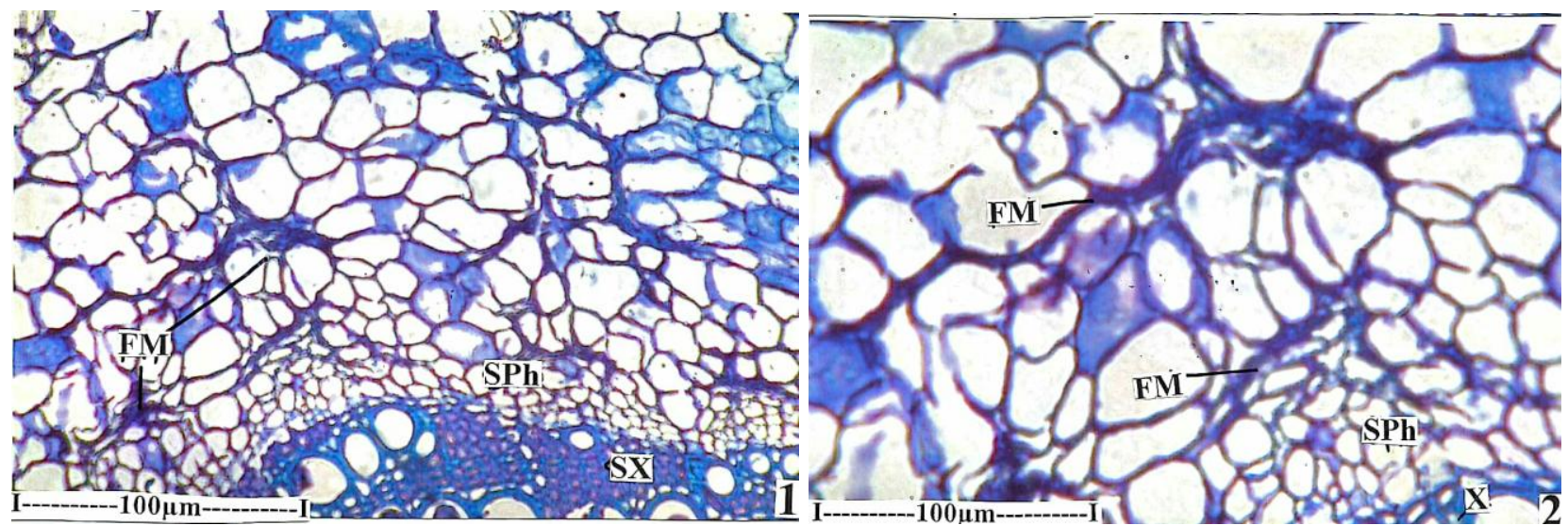

Fig. 4: Ormocarpum cochinchinense, (1) T.S. of root, the fungus with cortical cell. (2) Fungal mycelium enlarged (FM - Fungal Mycelium; X - Xylem; SX - Secondary xylem; SPh - Secondary Phloem)
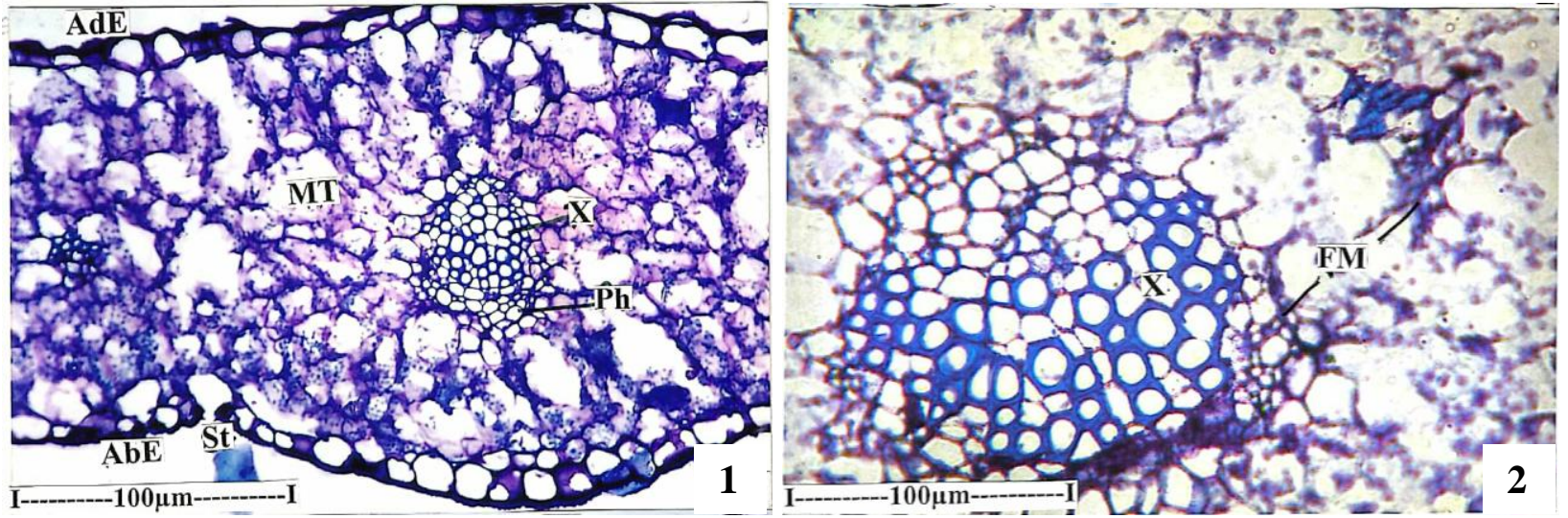

Fig. 5: Enicostema axillare, (1) T.S. of lamina and vein showing fungal mycelium in the mesophyll cells. (2) Vascular bundle of midrib - enlarged. (MT - Mesophyll Tissue; X - Xylem; Ph - Phloem; ABE - Abaxial epidermis; FM - Fungal mycelium).
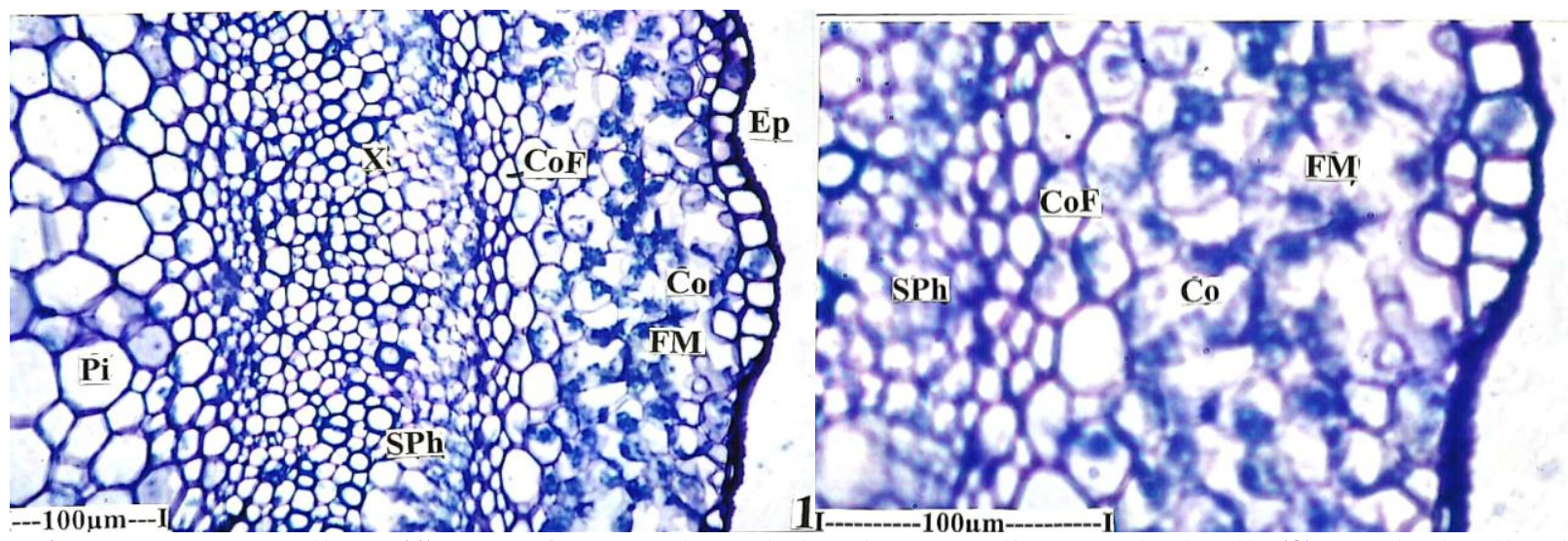

Fig. 6: Enicostema axillare, (1) T.S. of stem enlarged showing mycelium cortical cell. (2) Cortical cell enlarged (CoF - cortical fibres; X - Xylem; Ep - Epidermis; Co - Cortex; FM - Fungal mycelium; Pi - Pith; SPh Secondary Phloem). 


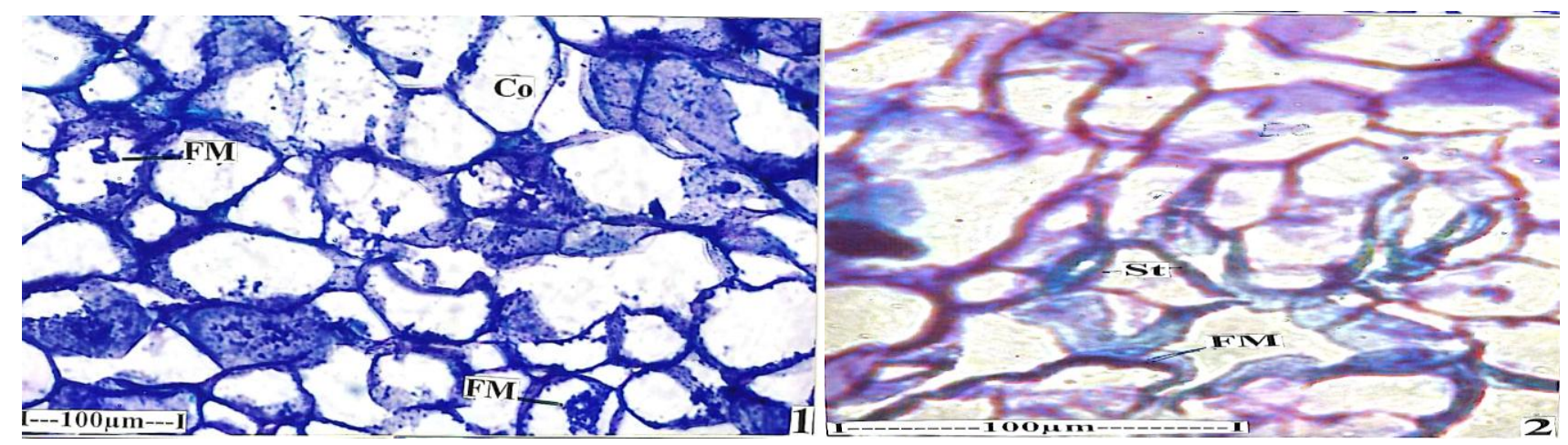

Fig.7: Enicostema axillare, (1) T.S. of root - showing cortical cells with fungal mycelium. (2) Leaf epidermal cells in surface view showing fungus (Co - Cortex; FM - Fungal Mycelium; St - Stoma).

\section{The benefits of the endophytic fungi association}

Endophytic fungi are those fungi that are found inside an organism. These fungi live in soil and have generally beneficial relationship with the vascular plants they infect. There are ecto (outside) mycorrhizae too. The endophytic hyphae (the long filamentous structures that characterize the nonfruiting part of a fungus, very hard to see with the unaided eye) that actually penetrate the cells in the plants roots. The ecto type's hyphae penetrates the roots but not inside the actual cell. Mycorrhizae are especially beneficial for the plant partner in nutrient poor soil, mycorrhizal plants are often more resistant to diseases, such as those caused by microbial soil - borne pathogens, and are also more resistant to the effects of drought, perhaps due to the improved water uptakes capability of the fungal hyphae. The fungus then kills the insects, perhaps with a toxin and sucks up nitrogen from the insects' bodies to nourish itself. The host plant takes any leftover nitrogen. In return, the plant supplies the fungi with energy - rich carbohydrates.

About 95percent of plants get nutrients such as nitrogen and phosphorus with help from various types of fungi. Fungi typically attach to plant roots and then send out fibrous branches, which can infiltrate dead matter. When that happens, the fungi break down the organic materials using enzymes and absorb nutrients.

Plant use of endophytic fungi in defense occurs when endophytic fungi, which live symbiotically with the majority of plants by entering their cells, are utilized as an indirect defense against herbivores. In exchange for carbohydrate energy resources, the fungus provides benefits to the plant which can include increased water or nutrient uptake and protection from phytophagous insects, birds or mammals. Once associated, or begin production of secondary metabolites. The change in chemical composition acts to deter hebivory by insects, grazing by ungulates and oviposition by adult insects. Endophyte - mediated defense can also be effective against pathogens and non herbivory damage.

This differs from others forms of indirect defense in that the fungi live within the plant cells and directly alter their physiology. In contrast, other biotic defenses such as predators or parasites of the herbivores consuming a plant are normally attracted by volatile organic compounds (known as semi chemicals) released following damage or by food rewards and shelter produced by the plant. These defenders vary in the time spent with the plant: from long enough to oviposit to remaining there for numerous generations, as in the ant - acacia mutualism. Endophytic fungi tend to live with the plant over its entire life.

The study conducted on anatomical features representing the presence of endophytic fungi from Ormocarpum cochinchinense and Enicostema axillare proves the presence of fungi in leaf and root tissues of Ormocarpum cochinchinense. The presence of endophytic fungi was found in tissues 
of leaf, root and stem in case of Enicostema axillare. The study is of first of its kind in establishing the relationship between plant and microbe interaction through anatomical studies.

\section{References}

Easu, K., 1964. Plant Anatomy. John Wiley and sons. New York. 767p.

Easu, K., 1979. Anatomy of Seed Plants. John Wiley and Sons, New York. 550p.

Gamble, J.S., 1935. Flora of the Presidency of Madras. Vol. I, II, \&III. Botanical Survey of India, Calcutta, India.

Hennry, A. N., Kumar, G.R., Chitra, V., 1987. Flora of Tamil Nadu, India. Vol. 3. Botanical Survey of India, Southern Circle, Combatore, India. 258p.

Johansen, D.A., 1940. Plant Microtechnique. McGraw Hill Book Co, New York. 523p.
Maria John, K. M., Deepa, V., Sandhiya, S., Karthik, S., Sampath, N., 2011. In vitro synthesis of calcite crystals from Ormocarpum cochinchinense (L.) a traditional bone healing aid of Southern India. Amer. J. Plant Physiol. 6, 312-317.

O'Brien, T.P., Feder, N., McCully, M. E., 1964. Polychromatic staining of plant cell walls by toluidine blue O. Protoplasma. 59(2), 368373.

Sass, J.E., 1940. Elements of Botanical Microtechnique. McGraw Hill Book Co., New York. 222p.

Vishwakarma, S., Sonawane, R.D., Rajani, M., Goyal, R. K., 2010. Evaluation of effect aqueous extract of Enicostemma littorale Blume in streptozotocin-induced Type 1 diabetic rats. Ind. J. Exp. Biol. 48, 26-30.

\section{How to cite this article:}

Nagarajan, D., Pandian, R., 2018. Anatomical studies on association of endophytic fungi in Ormocarpum cochinchinense and Enicostemma axillare. Int. J. Curr. Res. Biosci. Plant Biol. 5(1), 44-51.

doi: https://doi.org/10.20546/ijcrbp.2018.501.006 